\title{
Medicinal Plants and Zinc: Impact on COVID-19 Pandemic
}

\author{
Zineb Jalal, Meryem Bakour $\mathbb{D}^{\text {, }}$, and Badiaa Lyoussi \\ Laboratory of Natural Substances, \\ Pharmacology, Environment, Modeling, Health and Quality of Life (SNAMOPEQ). Faculty of Sciences Dhar El Mahraz, \\ University Sidi Mohamed Ben Abdellah, Fez, Morocco \\ Correspondence should be addressed to Badiaa Lyoussi; lyoussi@gmail.com
}

Received 24 May 2021; Revised 22 August 2021; Accepted 16 September 2021; Published 23 September 2021

Academic Editor: Ghadir A. El-Chaghaby

Copyright (c) 2021 Zineb Jalal et al. This is an open access article distributed under the Creative Commons Attribution License, which permits unrestricted use, distribution, and reproduction in any medium, provided the original work is properly cited.

\begin{abstract}
The world is currently grappling with the coronavirus disease (COVID-19) pandemic, caused by severe acute respiratory syndrome coronavirus 2 (SARS-CoV-2). The infection can cause fever, a dry cough, fatigue, severe pneumonia, respiratory distress syndrome, and in some cases death. There is currently no effective antiviral SARS-CoV-2 drug. To reduce the number of infections and deaths, it is critical to focus on strengthening immunity. This review aims to conduct a comprehensive search on the previous studies using Google Scholar, ScienceDirect, Medline, PubMed, and Scopus for the collection of research papers based on the role of zinc in the immune system, the antiviral activity of zinc, the effect of zinc supplementation in respiratory infections, the therapeutic approaches against viral infections based on medicinal plants, and the role of plants' bioactive molecules in fighting viral infections. In conclusion, we highlighted the pivotal role of zinc in antiviral immunity and we suggested the bioactive molecules derived from medicinal plants as a search matrix for the development of anti-SARS-CoV-2 drugs.
\end{abstract}

\section{Introduction}

Pandemic diseases are a global concern in the current era, as they cause enormous morbidity [1]. The rise of the density of inhabitants and the fast universal urbanization lead to many challenges to global health, such as the rapid spread of infectious diseases due to the close contact between people in urban areas and the emergence of slum settlements known by the poor access to clean water and sanitation [2]. With the advent of the twenty-first century, our planet has observed the incidence of catastrophic viral epidemics, namely, severe acute respiratory syndrome (SARS-CoV) and Middle East respiratory syndrome (MERS-CoV) in the human population [3]. Currently, coronavirus disease 2019 (COVID-19) is the third most important disease of animal origin, which prevails in all corners of the world. Nearly 219 countries on all continents have been affected in less than three months by this virus [4]. After studying its clinical features, experts founded that it is quite similar to pneumonia and hence named novel coronavirus. However, in the second week of March 2020, COVID-19 has been declared as a pandemic by the World Health Organization (WHO) [5]. The causative agent of COVID-19 is severe acute respiratory syndrome coronavirus 2 (SARS-CoV2) according to the official name of the International Committee on Taxonomy of Viruses (ICTV) [6]. To prevent the spread of COVID-19, the WHO has put in place recommendations such as frequent handwashing with soap and water or the use of a hydroalcoholic solution, stay away from anyone who coughs or sneezes, wear a mask when physical distancing is not possible, and avoid touching the eyes, nose, or mouth. In case of coughing or sneezing, cover the nose and mouth with the bend of the elbow or tissue [7]. The most common symptoms of COVID-19 are fever, cough, loss of smell, and myalgia [8]. Currently, existing antiviral drugs such as lopinavir, chloroquine, nitazoxanide, ritonavir, hydroxychloroquine, tocilizumab, and azithromycin have been used, which tend to reduce replication and viral load [9]. Furthermore, around the world, among hundreds of vaccines that have been tested in clinical trials, some of them have already been approved and the vaccination in several countries has already started [10].

In addition to that, zinc occupies an important place in the therapeutic strategy of the disease [11], given its important role in the functioning of the immune system and 
antiviral defense. The idea of the present review is to highlight the role of zinc in strengthening immunity and to reveal the importance of medicinal plants via their content on bioactive molecules to prevent or to treat COVID-19.

\section{Role of Zinc in the Immune System}

Zinc is an essential trace element for humans, it is involved in many physiological functions, and its deficiency can impact human health. Zinc intake is guaranteed in humans, thanks to nutrition. The amount of zinc in the body of an adult is approximately $1.4-2.3 \mathrm{~g}$, and it is the second most abundant ion after iron [12]. Zinc is essential for the activity of over 300 enzymes. It has multiple physiological roles. It is involved in the metabolism of proteins and fats [11].

The immune system is influenced by zinc on various levels. On the one hand, zinc specifically alters immune functions, and on the other hand, the immune system which is a highly proliferative "organ" is influenced by zinc-dependent proteins involved in general cellular functions, i.e., replication, transcription, and signal transduction [13]. All cell subsets of the immune response are affected by zinc. Decreased zinc levels impair natural killer cell activity, phagocytosis by macrophages and neutrophils, and certain functions such as chemotaxis and the oxidative burst [14]. However, zinc is important even for the maturation and functioning of T cells, since zinc is an essential cofactor for the thymus hormone thymulin [15]. This hormone has intrathymic and peripheral immunoregulatory properties, and it is necessary for an intact thymus $[16,17]$. Zinc deficiency thus leads to thymic atrophy; zinc also affects mature T cells. It induces the expression of the high-affinity receptor for interleukin-2, and zinc deficiency is associated with decreased $\mathrm{T}$-cell proliferation after mitogen stimulation $[18,19]$. Antibody production of B cells is also dependent on zinc. Interestingly, impaired antibody production can be restored through the addition of thymic cells, thus suggesting a T-cell-dependent defect [20]. Furthermore, the binding of zinc to immunoglobulins with as yet unclear functional relevance has been shown [21]. Additionally, it was reported that zinc can block the viral replication and prevent the excessive inflammatory reaction, and importantly, it was shown that zinc could react with the same receptor of SARS-CoV-2 (angiotensin-converting enzyme 2 receptor (ACE2)) and block its interaction with the spike proteins of the virus [22-24]. Overall, the clinical consequence of zinc deficiency is an impaired defense against bacterial, viral, and fungal infections (Figure 1).

\section{Antiviral Activity of Zinc}

The role of zinc in antiviral defense has been studied by several researchers through in vitro tests. Shishkov et al. have shown that zinc can specifically inactivate free varicellazoster virus virions [25]. Zaslavsky revealed the inhibition of the viral RNA and protein synthesis of the vaccinia virus using zinc sulfate $\left(\mathrm{ZnSO}_{4}\right)$ [26]. Similarly, Katz and Margalith showed that zinc chloride $\left(\mathrm{ZnCl}_{2}\right)$ inhibits the RNA synthesis and viral yield of the vaccinia virus [27].
Likewise, Wei et al. have shown that zinc can inhibit the viral RNA and protein synthesis of transmissible gastroenteritis virus [28]. Additionally, it has been shown that zinc can be effective in inhibiting other viruses such as Sindbis virus, Semliki Forest virus, respiratory syncytial virus, human papillomavirus, human immunodeficiency virus, rhinovirus, herpes simplex virus, and hepatitis $C$ virus. The mechanism of action of zinc against these viruses is variable as the inhibition of viral particle production and polyprotein cleavage, the inhibition of endosomal membrane fusion, the inhibition of viral polyprotein cleavage, the reduction in viral titer and plaque count, the stimulation of the proviral transcription factor activity, the inhibition of viral transcription and particle production, the inhibition of reverse transcriptase and viral protein synthesis, the inhibition of viral DNA polymerase, free virus inactivation, and the inhibition of RNA polymerase [23, 29-37]. Importantly, te Velthuis et al. have demonstrated that zinc can inhibit the replication of SARS-coronavirus (SARS-CoV) and equine arteritis virus (EAV) in cell culture [38].

The antiviral effect of zinc has been studied in vivo by many researchers via different routes of administration such as oral and topical. For instance, Godfrey et al. revealed that zinc reduced the severity of herpes simplex and the duration of treatment [39]. Similarly, Turner and Cetnarowski have shown that zinc reduced the duration of illness caused by rhinovirus [40]. In a randomized controlled trial, Murakami et al. studied the effect of zinc supplementation in chronic hepatitis $C$ patients treated with pegylated interferon (PEGIFN) alpha-2b plus ribavirin combination therapy; the comparison of the results obtained in the patients who received zinc and in the patients who did not receive it showed that the zinc supplementation decreased plasma thiobarbituric acid reactive substances, decreased the serum transaminases levels to within the normal range, and prevented the decrease of polyunsaturated fatty acids of erythrocyte membrane phospholipids [41]. Likewise, the results of a double-blind, placebo-controlled, clinical trial conducted by Eby et al. showed that zinc gluconate lozenges supplementation may reduce the symptom, the duration of treatment, and the severity of common cold [42].

Figure 1 was composed using Servier Medical Art templates, which are licensed under a Creative Commons Attribution 3.0 Unported License (http://smart.servier.com/).

\section{The Effect of Zinc Supplementation in Respiratory Infections}

Zinc is an essential micronutrient for the proper functioning of all organism cells; the body always requires a constant food supply of zinc because it does not store it. The problem of dietary zinc deficiency is very well known in developing countries [43]. The effect of zinc supplementation was studied as prophylactic or therapeutic strategies. Zinc supplementation in the therapeutic protocol of COVID-19 is supported by the results of many reports which have shown the beneficial effect of zinc supplementation against respiratory infections [44]. In a double-blind, randomized, controlled trial, the daily supplementation of $10 \mathrm{mg}$ of elemental zinc for 609 children revealed 


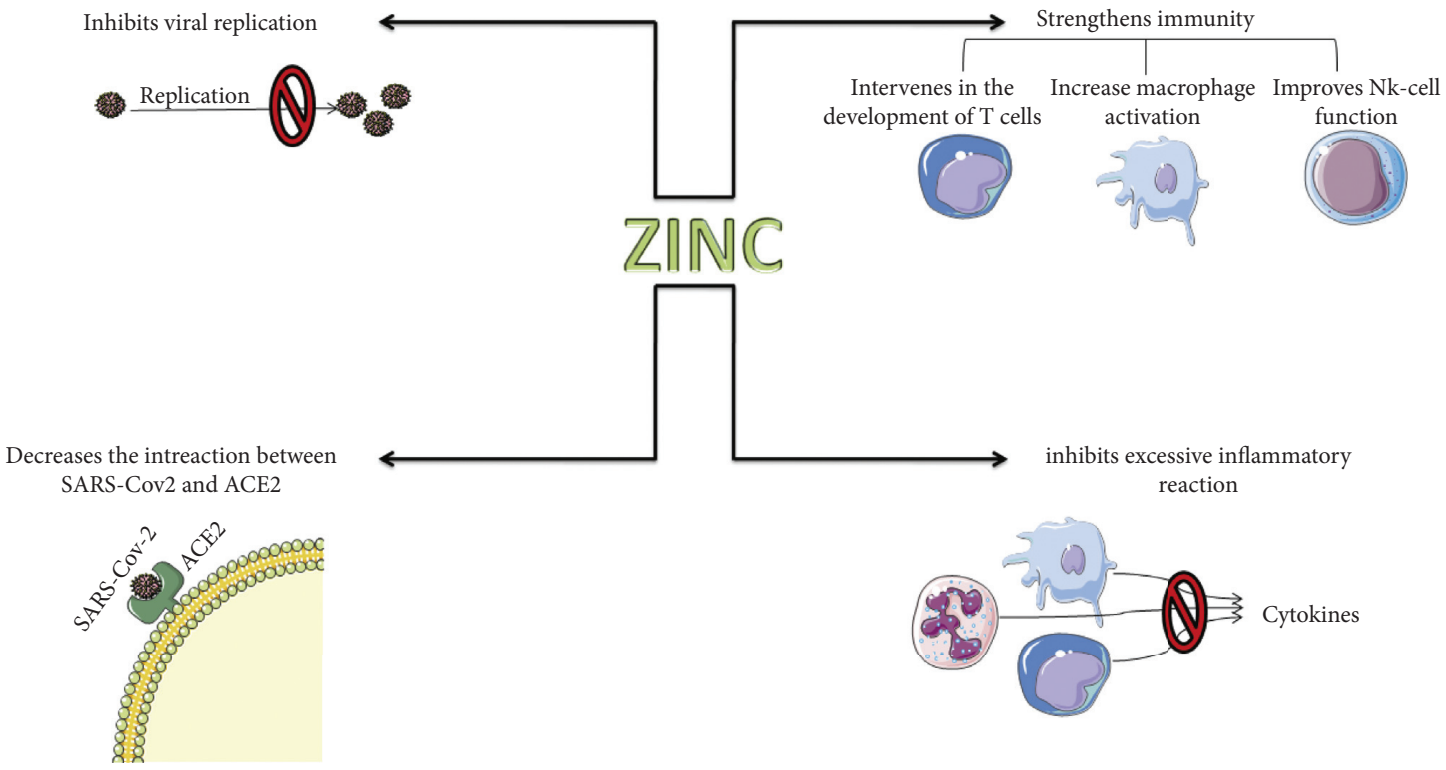

Figure 1: The role of zinc in the immune defense against SARS-CoV-2.

a significant reduction of the morbidity of acute lower respiratory infection [45]. In a pilot study published by Abdulhamid et al., the results indicated that the oral intake of $30 \mathrm{mg} /$ day of zinc reduced the number of days to treat children with oral antibiotics against cystic fibrosis [46]. Similarly, Rerksuppaphol and Rerksuppaphol conducted a randomized study in 64 hospitalized children with acute lower respiratory tract infections, and each child was randomly allocated to receive daily $30 \mathrm{mg}$ of elemental zinc or placebo. The results showed that zinc supplementation reduced the duration of hospital stay and improved the recovery of children [47].

Several clinical trials involving zinc as either a preventative or combination therapy showed a positive recovery from COVID-19. For instance, a case report conducted by Finzi suggested that zinc salt lozenges administrated orally (maximum $200 \mathrm{mg}$ ) played a role in clinical recovery and showed a significant improvement of the COVID-19 symptoms [48]. Likewise, the results of a phase IIa double-blind, randomized controlled trial revealed the safety, the feasibility, and the ability of high-dose intravenous zinc treatment in rectifying the acute phase zinc deficiency seen in hospitalized COVID-19 patients [49]. In addition, it has been shown by Frontera et al. that zinc with an ionophore treatment is associated with a reduction in in-hospital mortality among adult COVID-19 patients [50].

\section{Phytomedicines and COVID-19}

5.1. Therapeutic Approaches against Virus Based on Medicinal Plants. Despite scientific advances, viral diseases remain a matter of concern. In addition to the vaccines that are established to immunize people, the search for bioactive molecules with antiviral properties does not cease to stop. Among the matrices most exploited in research, we find medicinal plants. The world flora is rich in a variety of medicinal plants used for its special properties against human illness. Many herbal remedies are rich in active ingredients which have a broad-spectrum antiviral activity [51]. In the past, the discovery of the antiviral activity of various herbal remedies was limited due to the highly infectious nature of viruses and the lack of suitable separation methods for screening the antiviral components of plants [52]. Several scientific publications have reported the antiviral activity of plants, such as the study conducted by Nolkemper et al. showed that aqueous extracts of plants species from the Lamiaceae family (Rosmarinus officinalis, Melissa officinalis, Mentha x piperita, Prunella vulgaris, Salvia officinalis, and Thymus vulgaris) exhibited antiviral effect against herpes simplex virus type 1 and type 2 and the most important against an acyclovir-resistant strain of $\mathrm{HCV}-1$ $\left(\mathrm{ACV}^{\mathrm{res}}\right)$ [53]. The phytochemical analysis of these plants revealed their richness in polyphenolic compounds known by their antiviral activities such as rosmarinic acid, caffeic acid, apigenin, eriodictyol, and luteolin derivatives [54]. Likewise, Song et al. showed that the 3-galloyl group of catechin skeleton from the green tea (Camellia sinensis) plays an important role in the antiviral activity of this plant against influenza virus (A/ $\mathrm{H} 1 \mathrm{~N} 1, \mathrm{~A} / \mathrm{H} 3 \mathrm{~N} 2$, and $\mathrm{B}$ virus) by the alteration of the physical properties of the viral membrane [55]. Additionally, Bayan et al. have shed light on the antiviral effect of the biologically active compounds of garlic (allicin, diallyl trisulfide, alliin, diallyl sulfide, and diallyl disulfide) against influenza A and B, HIV, HSV-1, viral pneumonia, cytomegalovirus, and rhinovirus [56].

Punicalagin is an active compound of pomegranate which had a virucidal property against influenza virus (influenza virus $\mathrm{A} ; \mathrm{H} 3 \mathrm{~N} 2 ; \mathrm{H} 1 \mathrm{~N} 1$ and influenza B); it inhibits the replication of the viral RNA. Interestingly, it has been 
shown that the combination of polyphenolic pomegranate extract and oseltamivir increases the anti-influenza effect of oseltamivir [57].

During the outbreak of COVID-19, various medicinal plant formulations recommended in traditional medicine have been used by people to alleviate symptoms associated with the SARS-CoV-2 infection. In a review study published by Luo et al., it was reported that the most used plants by 23 provinces in China for the prevention of COVID-19 were Fructus forsythia, Radix astragali, Radix saposhnikoviae, Lonicerae japonicae flos, Rhizoma Atractylodis macrocephalae, and Radix glycyrrhizae [58]. Likewise, Ulasli et al. have shown that the extracts of Nigella sativa, Citrus sinensis, and Anthemis hyalina can decrease the replication of SARS-CoV-2 and decrease the expression of the TRP genes family [59]. Similarly, in a study conducted by Lin et al., root water extract of Isatis indigotica and its five major compounds (indigo, indirubin, indican, sinigrin, and beta-sitosterol) were tested against 3C-like protease (3CLpro) of SARS-coronavirus, and the results demonstrated that the root extract and two major compounds (indigo and sinigrin) were efficient in the inhibition of 3CLpro of the virus [60] (Table 1).

5.2. Role of Plants' Secondary Metabolites. Secondary metabolites are groups of molecules that are essential for the adaptation of plants to their environment. They are divided into phenolics, terpenes, alkaloids, and steroids [61]. Among the most important secondary metabolites, which have a broad spectrum of biological effects, we found polyphenols, a family of organic molecules composed mainly of phenolic acids, and flavonoids, which are widely present in the plants [62], and they have many functional properties such as antioxidant activity [63], anticancer effect [64], and antiviral effect [65].

It was reported that phenolic compounds, such as quercetin, curcumin, and resveratrol, could modulate the expression of miRNAs in the host cells infected with SARSCoV-2 [66]. Chiang et al. have demonstrated the antiviral effect of purified compounds from Ocimum basilicum (apigenin, linalool, and ursolic acid) against the following virus: herpes viruses (HSV), adenoviruses (ADV), hepatitis $\mathrm{B}$ virus, coxsackievirus B1 (CVB1), and enterovirus 71 (EV71) [67]. Similarly, it was found that carnosic acid isolated from the ethyl acetate fraction of Rosmarinus officinalis was effective against the human respiratory syncytial virus (hRSV) [68].

Caffeic acid and chlorogenic acid are two phenolic acid compounds found in Plantago major, the antiviral effect of this plant has been revealed against HSV-1, HSV-2, ADV-3, and ADV-11 viruses [69].

Baicalin is a flavonoid compound found in Scutellaria baicalensis Georgi [70]; it can inhibit the viral replication of human immunodeficiency virus type 1 (HIV-1) [71]. Recently, it was reported that this flavonoid exhibited potent antiviral activity against SARS-CoV-2 via the inhibition of SARS-CoV-2 3CL protease in a cell-based system [72].

Concerning the antiviral effect of terpenes compounds, it was reported that Laurus nobilis essential oil (main chemical constituents: $\beta$-ocimene, $\alpha$-pinene, $\beta$-pinene, and 1,8-cineole) was effective against SARS-CoV $\left(\mathrm{IC}_{50}\right.$ value $=120 \pm 1.2 \mathrm{mg} / \mathrm{ml}$ ) [73]. Sharifi-Rad et al. have demonstrated the antiviral effect of thymol, which is an aromatic compound from the monoterpene group, found in thyme essential oil, against herpes simplex virus type 1 (HSV-1) [74].

In a study published by Wen et al., ten diterpenoids, two sesquiterpenoids, and two triterpenoids were tested against SARS-CoV using a cell-based assay measuring SARS-CoVinduced cytopathogenic effect on Vero E6 cells. The results showed that these phytochemical constituents of essential oil have a significant anti-SARS-CoV effect [75].

Alkaloids are other types of secondary metabolites that contribute to the antiviral activity of plants. For instance, it was shown recently by Chen et al. the efficacy of lycorine, a toxic crystalline alkaloid found in plants belonging to the Amaryllidaceae family, against the Zika virus [76]. More importantly, Zhang et al. have proved the antiviral effect of lycorine and oxysophoridine (an alkaloid found in Sophora alopecuroides) against SARS-CoV-2 in cell culture by the inhibition of viral replication [77].

Lycoris radiata is another plant belonging to the Amaryllidaceae family, and it was reported that it is effective against SARS-CoV-2, thanks to its content on its main active compounds: lycorine and glycyrrhizin [78]. The last one is a triterpenoid saponin mainly found in Glycyrrhiza glabra roots; the antiviral effect of glycyrrhizin is well documented $[79,80]$. Recently, it took the attention of many researchers to test it against SARS-CoV-2, and it was reported that it can bind to the same SARS-CoV-2 receptor (the angiotensinconverting enzyme 2 (ACE2) receptor) [80].

5.3. The Content of Medicinal Plants on Zinc. As previously signaled, zinc supplementation has a beneficial effect in strengthening the immune system; Table 2 provides a list of medicinal plants analyzed in various countries of the world for their zinc content. In Morocco, the following plants were analyzed: Artemisia herba alba, Thymus vulgaris, Lavandula dentata, Rosmarinus tournefortii, Pistacia lentiscus, Pistacia lentiscus, Retama monosperma, Retama monosperma, Ziziphus spina-christi, and Ziziphus lotus; the zinc content in these plants ranged between $28 \pm 6 \mathrm{mg} / \mathrm{kg}$ in the pulp of Ziziphus lotus and $1016.73 \mathrm{mg} / \mathrm{kg}$ in leaves of Rosmarinus tournefortii [81-85]. Similarly, Citrullus colocynthis, Balanites aegyptiaca, Solenostemma argel, Pergularia tomentosa, Acacia albida, Acacia ehrenbergiana, and Cymbopogon proximus from Egypt were analyzed by Sheded et al. for the zinc content and revealed the following values: $25.87 \pm 3.4 \mathrm{mg} / \mathrm{kg}, \quad 15.47 \pm 3 \mathrm{mg} / \mathrm{kg}, \quad 73.77 \pm 3.8 \mathrm{mg} / \mathrm{kg}$, $58.47 \pm 5.3 \mathrm{mg} / \mathrm{kg}, \quad 30.27 \pm 14.4 \mathrm{mg} / \mathrm{kg}$, and $16.77 \pm 4.4 \mathrm{mg} /$ $\mathrm{kg}$, respectively [86]. Ebrahim et al. found that the range of zinc content was between $3.34 \pm 0.2 \mathrm{mg} / \mathrm{kg}$ and $58.80 \pm 2.1 \mathrm{mg} / \mathrm{kg}$ in Sesamum indicum, Olea europaea, Vaccinium myrtillus, Nigella sativa, Trigonella foenumgraecum, Pennisetum glaucum, Calligonum comosum, Citrullus colocynthis, Momordica charantia, Opuntia ficusindica, and Haloxylon salicornicum from Saudi Arabia [84]. 
TABle 1: Antiviral effect of medicinal plants.

\begin{tabular}{|c|c|c|c|}
\hline Medicinal plant & Active compounds & Antiviral effect & Reference \\
\hline $\begin{array}{l}\text { Rosmarinus } \\
\text { officinalis }\end{array}$ & Phenolic compounds & $\begin{array}{l}\text { Herpes simplex virus type } 1 \text { and type } 2 \text { and } \\
\text { acyclovir-resistant strain of } \mathrm{HCV}-1\left(\mathrm{ACV}^{\text {res }}\right)\end{array}$ & {$[53]$} \\
\hline $\begin{array}{l}\text { Melissa } \\
\text { officinalis }\end{array}$ & Phenolic compounds & $\begin{array}{l}\text { Herpes simplex virus type } 1 \text { and type } 2 \text { and } \\
\text { acyclovir-resistant strain of } \mathrm{HCV}-1\left(\mathrm{ACV}^{\mathrm{res}}\right)\end{array}$ & {$[53]$} \\
\hline $\begin{array}{l}\text { Mentha } x \\
\text { piperita }\end{array}$ & Phenolic compounds & $\begin{array}{l}\text { Herpes simplex virus type } 1 \text { and type } 2 \text { and } \\
\text { acyclovir-resistant strain of } \mathrm{HCV}-1\left(\mathrm{ACV}^{\mathrm{res}}\right)\end{array}$ & {$[53]$} \\
\hline $\begin{array}{l}\text { Prunella } \\
\text { vulgaris }\end{array}$ & Phenolic compounds & $\begin{array}{l}\text { Herpes simplex virus type } 1 \text { and type } 2 \text { and } \\
\text { acyclovir-resistant strain of } \mathrm{HCV}-1\left(\mathrm{ACV}^{\mathrm{res}}\right)\end{array}$ & {$[53]$} \\
\hline Salvia officinalis & Phenolic compounds & $\begin{array}{l}\text { Herpes simplex virus type } 1 \text { and type } 2 \text { and } \\
\text { acyclovir-resistant strain of } \mathrm{HCV}-1\left(\mathrm{ACV}^{\text {res }}\right)\end{array}$ & {$[53]$} \\
\hline Thymus vulgaris & Phenolic compounds & $\begin{array}{l}\text { Herpes simplex virus type } 1 \text { and type } 2 \text { and } \\
\text { acyclovir-resistant strain of } \mathrm{HCV}-1\left(\mathrm{ACV}^{\text {res }}\right)\end{array}$ & {$[53]$} \\
\hline $\begin{array}{l}\text { Camellia } \\
\text { sinensis }\end{array}$ & $\begin{array}{c}\text { Catechins ((-)-epigallocatechin gallate (EGCG), } \\
(-) \text {-epicatechin gallate (ECG), and (-)-epigallocatechin } \\
(\mathrm{EGC}))\end{array}$ & $\mathrm{A} / \mathrm{H} 1 \mathrm{~N} 1, \mathrm{~A} / \mathrm{H} 3 \mathrm{~N} 2$, and $\mathrm{B}$ virus & {$[55]$} \\
\hline Allium sativum & Allicin, alliin, diallyl sulfide, diallyl disulfide & $\begin{array}{c}\text { Influenza A and B, HIV, HSV-1, viral } \\
\text { pneumonia, cytomegalovirus, and rhinovirus }\end{array}$ & {$[56]$} \\
\hline $\begin{array}{l}\text { Punica } \\
\text { granatum }\end{array}$ & Punicalagin & Influenza virus $\mathrm{A} ; \mathrm{H} 3 \mathrm{~N} 2 ; \mathrm{H} 1 \mathrm{~N} 1$ and influenza $\mathrm{B}$ & {$[57]$} \\
\hline
\end{tabular}

TABle 2: The zinc content of medicinal plants.

\begin{tabular}{|c|c|c|c|c|}
\hline Name of plants & Country & Part used & Content in zinc & Reference \\
\hline Artemisia herba alba & Morocco & Leaves & 377.89 to $798.21 \mathrm{mg} / \mathrm{kg}$ & {$[81]$} \\
\hline Thymus vulgaris & Morocco & Leaves + flowers & 359.46 to $415.33 \mathrm{mg} / \mathrm{kg}$ & {$[81]$} \\
\hline Lavandula dentata & Morocco & Leaves + flowers & $480.39 \mathrm{mg} / \mathrm{kg}$ & [81] \\
\hline Rosmarinus tournefortii & Morocco & Leaves & $1016.73 \mathrm{mg} / \mathrm{kg}$ & {$[81]$} \\
\hline Justicia adhatoda L. & Pakistan & Whole plant & $31.64 \pm 7.84 \mathrm{ppm}$ & [90] \\
\hline Achyranthes aspera L. & Pakistan & Whole plant & $20.91 \pm 4.61 \mathrm{ppm}$ & [90] \\
\hline Alternanthera pungens Kunth & Pakistan & Whole plant & $37.86 \pm 2.76 \mathrm{ppm}$ & {$[90]$} \\
\hline Parthenium hysterophorus L. & Pakistan & Whole plant & $28.92 \pm 9.18 \mathrm{ppm}$ & [90] \\
\hline Cannabis sativa $\mathrm{L}$. & Pakistan & Leaves & $29.45 \pm 4.81 \mathrm{ppm}$ & {$[90]$} \\
\hline Ricinus communis L. & Pakistan & Whole plant & $31.55 \pm 4.20 \mathrm{ppm}$ & [90] \\
\hline Hordeum vulgare L. & Pakistan & Seeds & $65.85 \pm 1.06 \mathrm{ppm}$ & [90] \\
\hline Withania somnifera (L.) Dunal & Pakistan & Whole plant & $22.33 \pm 3.63 \mathrm{ppm}$ & {$[90]$} \\
\hline Citrullus colocynthis & Egypt & Whole plant & $25.87 \pm 3.4 \mathrm{mg} / \mathrm{kg}$ & {$[86]$} \\
\hline Balanites aegyptiaca & Egypt & Whole plant & $15.47 \pm 3.0 \mathrm{mg} / \mathrm{kg}$ & [86] \\
\hline Solenostemma argel & Egypt & Whole plant & $73.77 \pm 3.8 \mathrm{mg} / \mathrm{kg}$ & {$[86]$} \\
\hline Pergularia tomentosa & Egypt & Whole plant & $58.47 \pm 5.3 \mathrm{mg} / \mathrm{kg}$ & {$[86]$} \\
\hline Acacia albida & Egypt & Whole plant & $30.27 \pm 14.4 \mathrm{mg} / \mathrm{kg}$ & {$[86]$} \\
\hline Acacia ehrenbergiana & Egypt & Whole plant & $16.77 \pm 4.4 \mathrm{mg} / \mathrm{kg}$ & {$[86]$} \\
\hline Cymbopogon proximus & Egypt & Whole plant & $25.77 \pm 5.3 \mathrm{mg} / \mathrm{kg}$ & {$[86]$} \\
\hline Sesamum indicum & Saudi Arabia & Seeds & $54.90 \pm 1.9 \mathrm{mg} / \mathrm{kg}$ & {$[84]$} \\
\hline Olea europaea & Saudi Arabia & Leaves & $7.79 \pm 0.5 \mathrm{mg} / \mathrm{kg}$ & {$[84]$} \\
\hline Vaccinium myrtillus & Saudi Arabia & Fruit & $3.34 \pm 0.2 \mathrm{mg} / \mathrm{kg}$ & {$[84]$} \\
\hline Nigella sativa & Saudi Arabia & Seeds & $58.80 \pm 2.1 \mathrm{mg} / \mathrm{kg}$ & {$[84]$} \\
\hline Trigonella foenum-graecum & Saudi Arabia & Seeds & $29.80 \pm 1.3 \mathrm{mg} / \mathrm{kg}$ & {$[84]$} \\
\hline Pennisetum glaucum & Saudi Arabia & Seeds & $34.00 \pm 1.5 \mathrm{mg} / \mathrm{kg}$ & {$[84]$} \\
\hline Calligonum comosum & Saudi Arabia & Whole plant & $11.80 \pm 0.6 \mathrm{mg} / \mathrm{kg}$ & {$[84]$} \\
\hline Citrullus colocynthis & Saudi Arabia & Fruit & $12.80 \pm 0.6 \mathrm{mg} / \mathrm{kg}$ & {$[84]$} \\
\hline Momordica charantia & Saudi Arabia & Fruit & $21.20 \pm 1.1 \mathrm{mg} / \mathrm{kg}$ & {$[84]$} \\
\hline Opuntia ficus-indica & Saudi Arabia & Fruit & $14.30 \pm 0.7 \mathrm{mg} / \mathrm{kg}$ & {$[84]$} \\
\hline Haloxylon salicornicum & Saudi Arabia & Whole plant & $6.67 \pm 0.4 \mathrm{mg} / \mathrm{kg}$ & {$[84]$} \\
\hline Pistacia lentiscus & Morocco & Leaves & $230.36 \mathrm{mg} / \mathrm{kg}$ & {$[82]$} \\
\hline Pistacia lentiscus & Morocco & Fruits & $168.11 \mathrm{mg} / \mathrm{kg}$ & {$[82]$} \\
\hline Retama monosperma & Morocco & Branches/leaves & $140.91 \mathrm{mg} / \mathrm{kg}$ & [83] \\
\hline Retama monosperma & Morocco & Seeds & $44.33 \mathrm{mg} / \mathrm{kg}$ & [83] \\
\hline Ziziphus spina-christi & Morocco & Fruit & $0.44 \pm 0.06 \mathrm{mg} / 100 \mathrm{~g}$ & {$[85]$} \\
\hline Ziziphus spina-christi & Morocco & Pulp & $0.38 \pm 0.03 \mathrm{mg} / 100 \mathrm{~g}$ & {$[85]$} \\
\hline
\end{tabular}


TABLE 2: Continued.

\begin{tabular}{|c|c|c|c|c|}
\hline Name of plants & Country & Part used & Content in zinc & Reference \\
\hline Ziziphus spina-christi & Morocco & Seed & $0.65 \pm 0.04 \mathrm{mg} / 100 \mathrm{~g}$ & {$[85]$} \\
\hline Ziziphus spina-christi & Morocco & Almond & $0.86 \pm 0.05 \mathrm{mg} / 100 \mathrm{~g}$ & {$[85]$} \\
\hline Ziziphus lotus & Morocco & Fruit & $0.31 \pm 0.01 \mathrm{mg} / 100 \mathrm{~g}$ & {$[85]$} \\
\hline Ziziphus lotus & Morocco & Pulp & $0.28 \pm 0.06 \mathrm{mg} / 100 \mathrm{~g}$ & {$[85]$} \\
\hline Ziziphus lotus & Morocco & Seed & $0.59 \pm 0.04 \mathrm{mg} / 100 \mathrm{~g}$ & {$[85]$} \\
\hline Ziziphus lotus & Morocco & Almond & $0.78 \pm 0.04 \mathrm{mg} / 100 \mathrm{~g}$ & {$[85]$} \\
\hline Amaranthus viridis & India & Leaves & $9.73 \pm 1.02 \mathrm{mg} / 100 \mathrm{~g}$ & {$[87]$} \\
\hline Chenopodium album & India & Leaves & $8.44 \pm 0.9 \mathrm{mg} / 100 \mathrm{~g}$ & [87] \\
\hline Diplazium esculentum & India & Leaves & $2.73 \pm 0.1 \mathrm{mg} / 100 \mathrm{~g}$ & [87] \\
\hline Nasturtium officinale & India & Leaves & $2.04 \pm 0.03 \mathrm{mg} / 100 \mathrm{~g}$ & {$[87]$} \\
\hline Urtica dioica & India & Leaves & $2.32 \pm 0.04 \mathrm{mg} / 100 \mathrm{~g}$ & {$[87]$} \\
\hline Allium neapolitanum & Turkey & Bulb & $234.969 \pm 9.04 \mathrm{mg} / \mathrm{kg}$ & [91] \\
\hline Allium scorodoprasum & Turkey & Bulb & $386.150 \pm 12.84 \mathrm{mg} / \mathrm{kg}$ & [91] \\
\hline Cichorium intybus & Turkey & Root & $257.858 \pm 5.48 \mathrm{mg} / \mathrm{kg}$ & {$[91]$} \\
\hline Ferula communis & Turkey & Rhizome & $302.083 \pm 6.18 \mathrm{mg} / \mathrm{kg}$ & [91] \\
\hline Glycyrrhiza glabra & Turkey & Rhizome & $182.978 \pm 2.93 \mathrm{mg} / \mathrm{kg}$ & {$[91]$} \\
\hline Laurus nobilis & Turkey & Seed & $281.449 \pm 5.86 \mathrm{mg} / \mathrm{kg}$ & [91] \\
\hline Paliurus spina-christi & Turkey & Fruit & $177.784 \pm 6.91 \mathrm{mg} / \mathrm{kg}$ & {$[91]$} \\
\hline Papaver somniferum & Turkey & Seed & $330.341 \pm 4.09 \mathrm{mg} / \mathrm{kg}$ & [91] \\
\hline Pinus brutia & Turkey & Resin & $174.993 \pm 5.83 \mathrm{mg} / \mathrm{kg}$ & [91] \\
\hline Pistacia terebinthus & Turkey & Fruits & $173.171 \pm 6.86 \mathrm{mg} / \mathrm{kg}$ & [91] \\
\hline Quercus infectoria & Turkey & Gall & $166.910 \pm 2.69 \mathrm{mg} / \mathrm{kg}$ & {$[91]$} \\
\hline Rhus coriaria & Turkey & Seed & $307.730 \pm 6.94 \mathrm{mg} / \mathrm{kg}$ & [91] \\
\hline Ricinus communis & Turkey & Seed & $395.252 \pm 12.92 \mathrm{mg} / \mathrm{kg}$ & [91] \\
\hline
\end{tabular}

Indian medicinal plants were studied by Pradhan et al., Datta et al., and Matev et al. [87-89]; the results showed a content in zinc ranged between $2.01 \pm 0.1 \mathrm{mg} / 100 \mathrm{~g}$ in Albizia lebbeck seeds and $50 \pm 1 \mathrm{mg} / 100 \mathrm{~g}$ in Achyranthes aspera (whole plant). Additionally, Pakistani plants were analyzed by Jabben et al. [90] and revealed a zinc content ranged between $22.33 \pm 3.63 \mathrm{ppm}$ in Withania somnifera and $65.85 \pm 1.06 \mathrm{ppm}$ in Hordeum vulgare. Plants from Turkey showed that the zinc content ranged between $53 \mathrm{mg} / \mathrm{kg}$ in Punica granatum fruits and $395.252 \pm 12.92 \mathrm{mg} / \mathrm{kg}$ in Ricinus communis seeds [91, 92]. Similarly, $2.84 \pm 0.005 \mathrm{mg} /$ $100 \mathrm{~g}$ of zinc was found in Ficus capensis from Nigeria [93]. The range of zinc in Romanian plants was between $20.83 \pm 1.11 \mu \mathrm{g} / \mathrm{kg}$ in Lavandula angustifolia and $64.76 \pm 0.53 \mu \mathrm{g} / \mathrm{kg}$ in Althaea officinalis [94], while the leaves of Eruca sativa from Italia and Bulgaria revealed a zinc content of $15.07 \pm 0.60 \mathrm{mg} / \mathrm{kg}$ and $91.05 \pm 0.65 \mathrm{mg} / \mathrm{kg}$, respectively [95] (Table 2).

\section{Conclusion}

The world is facing a serious health crisis due to the emergence of a novel coronavirus (SARS-CoV-2). It is essential to find effective and safe solutions to reduce the morbidity and mortality caused by this pandemic situation. In this review, we discussed the evidence surrounding the role of zinc supplementation in strengthening immunity and in the recovery of patients with COVID-19. In addition, we proposed a list of medicinal plants as a source of bioactive molecules endowed with antiviral activities such as quercetin, curcumin, resveratrol, baicalin, allicin, punicalagin, lycorine, glycyrrhizin, and other secondary metabolites. This review will facilitate laboratory-based research and stimulate further analysis for the development of novel drugs to solve the current crisis.

\section{Data Availability}

The data used to support the findings of this study are included within the article.

\section{Conflicts of Interest}

The authors declare that they have no conflicts of interest.

\section{Authors' Contributions}

All authors contributed equally to this paper.

\section{References}

[1] A. Ahmad, M. U. Rehman, and K. M. Alkharfy, "an alternative approach to minimize the risk of coronavirus (Covid-19) and similar infections," European Review for Medical and Pharmacological Sciences, vol. 24, no. 7, pp. 4030-4034, 2020.

[2] C.-J. Neiderud, "How urbanization affects the epidemiology of emerging infectious diseases," Infection Ecology \& Epidemiology, vol. 5, no. 1, Article ID 27060, 2015.

[3] R. Čivljak, A. Markotić, and I. Kuzman, "The third coronavirus epidemic in the third millennium: what's next?" Croatian Medical Journal, vol. 61, no. 1, pp. 1-4, 2020.

[4] M.-G. Hâncean, M. Slavinec, and M. Perc, "The impact of human mobility networks on the global spread of COVID19," Journal of Complex Networks, vol. 8, no. 6, 2021.

[5] P. Gautret, J.-C. Lagier, P. Parola et al., "Hydroxychloroquine and azithromycin as a treatment of COVID-19: results of an open-label non-randomized clinical trial," International 
Journal of Antimicrobial Agents, vol. 56, no. 1, Article ID 105949, 2020.

[6] C. S. G. of the International, "The species Severe acute respiratory syndrome-related coronavirus: classifying 2019$\mathrm{nCoV}$ and naming it SARS-CoV-2," Nature Microbiology, vol. 5, no. 4, pp. 536-544, 2020.

[7] World Health Organization, Rational Use of Personal Protective Equipment (PPE) for Coronavirus Disease (COVID-19): Interim Guidance, 19 March 2020, World Health Organization, Geneva, Switzerland, 2020.

[8] S. Muralidar, S. V. Ambi, S. Sekaran, and U. M. Krishnan, "The emergence of COVID-19 as a global pandemic: understanding the epidemiology, immune response and potential therapeutic targets of SARS-CoV-2," Biochimie, vol. 179 , pp. 85-100, 2020.

[9] Y. Peng, H. Tao, S. K. Satyanarayanan, K. Jin, and H. Su, “A comprehensive summary of the knowledge on COVID-19 treatment," Aging and disease, vol. 12, no. 1, pp. 155-191, 2021.

[10] M. Machida, I. Nakamura, T. Kojima et al., "Acceptance of a COVID-19 vaccine in Japan during the COVID-19 pandemic," Vaccines, vol. 9, no. 3, p. 210, 2021.

[11] N. Samad, T. E. Sodunke, A. R. Abubakar et al., "The implications of zinc therapy in combating the COVID-19 global pandemic," Journal of Inflammation Research, vol. 14, pp. 527-550, 2021.

[12] C. T. Chasapis, A. C. Loutsidou, C. A. Spiliopoulou, and M. E. Stefanidou, "Zinc and human health: an update," $A r$ chives of Toxicology, vol. 86, no. 4, pp. 521-534, 2012.

[13] B. L. Vallee and K. H. Falchuk, "The biochemical basis of zinc physiology," Physiological Reviews, vol. 73, no. 1, pp. 79-118, 1993.

[14] C. L. Keen and M. E. Gershwin, "Zinc deficiency and immune function," Annual Review of Nutrition, vol. 10, no. 1, pp. $415-431,1990$.

[15] A. E. Calder, M. N. Hince, J. A. Dudakov, A. P. Chidgey, and R. L. Boyd, "Thymic involution: where endocrinology meets immunology," Neuroimmunomodulation, vol. 18, no. 5, pp. 281-289, 2011.

[16] L. Rink, "Zinc and the immune system," Proceedings of the Nutrition Society, vol. 59, no. 4, pp. 541-552, 2000.

[17] J.-F. Bach, "The multi-faceted zinc dependency of the immune system," Immunology Today, vol. 2, no. 11, pp. 225-227, 1981.

[18] J. Kruse-Jarres, "the significance of zinc for humoral and cellular immunity," Journal of Trace Elements \& Electrolytes in Health \& Disease, vol. 3, no. 1, pp. 1-8, 1989.

[19] P. S. Dowd, J. Kelleher, and P. J. Guillou, "T-lymphocyte subsets and interleukin-2 production in zinc-deficient rats," British Journal of Nutrition, vol. 55, no. 1, pp. 59-69, 1986.

[20] M. Maares and H. Haase, "Zinc and immunity: an essential interrelation," Archives of Biochemistry and Biophysics, vol. 611, pp. 58-65, 2016.

[21] A. S. Prasad and D. Oberleas, "Binding of zinc to amino acids and serum proteins in vitro," The Journal of Laboratory and Clinical Medicine, vol. 76, no. 3, pp. 416-425, 1970.

[22] S. W. McPherson, J. E. Keunen, A. C. Bird, E. Y. Chew, and F. J. van Kuijk, "Investigate oral zinc as a prophylactic treatment for those at risk for COVID-19," American Journal of Ophthalmology, vol. 216, pp. A5-A6, 2020.

[23] R. O. Suara and J. E. Crowe, "Effect of zinc salts on respiratory syncytial virus replication," Antimicrobial Agents and Chemotherapy, vol. 48, no. 3, pp. 783-790, 2004.

[24] H. Haase and L. Rink, "Functional significance of zinc-related signaling pathways in immune cells," Annual Review of Nutrition, vol. 29, no. 1, pp. 133-152, 2009.
[25] S. Shishkov, T. Varadinova, P. Bontchev, C. Nachev, and E. Michailova, "Complexes of zinc with picolinic and aspartic acids inactivate free varicella-zoster virions," Metal-Based Drugs, vol. 3, no. 1, pp. 11-14, 1996.

[26] V. Zaslavsky, "Inhibition of vaccinia virus growth by zinc ions: effects on early RNA and thymidine kinase synthesis," Journal of Virology, vol. 29, no. 1, pp. 405-408, 1979.

[27] E. Katz and E. Margalith, "Inhibition of vaccinia virus maturation by zinc chloride," Antimicrobial Agents and Chemotherapy, vol. 19, no. 2, pp. 213-217, 1981.

[28] Z. Wei, M. Burwinkel, C. Palissa, E. Ephraim, and M. F. G. Schmidt, "Antiviral activity of zinc salts against transmissible gastroenteritis virus in vitro," Veterinary $\mathrm{Mi}$ crobiology, vol. 160, no. 3-4, pp. 468-472, 2012.

[29] M. Bracha and M. J. Schlesinger, "Inhibition of Sindbis virus replication by zinc lons," Virology, vol. 72, no. 1, pp. 272-277, 1976.

[30] J. Corver, R. Bron, H. Snippe, C. Kraaijeveld, and J. Wilschut, "Membrane fusion activity of semliki forest virus in a liposomal model system: specific inhibition by $\mathrm{Zn} 2+$ Ions," $V i$ rology, vol. 238, no. 1, pp. 14-21, 1997.

[31] B. D. Korant, J. C. Kauer, and B. E. Butterworth, "Zinc ions inhibit replication of rhinoviruses," Nature, vol. 248, no. 5449, pp. 588-590, 1974.

[32] M. Lazarczyk, C. Pons, J.-A. Mendoza, P. Cassonnet, Y. Jacob, and M. Favre, "Regulation of cellular zinc balance as a potential mechanism of EVER-mediated protection against pathogenesis by cutaneous oncogenic human papillomaviruses," Journal of Experimental Medicine, vol. 205, no. 1, pp. 35-42, 2008.

[33] K. J. Fenstermacher and J. J. DeStefano, "Mechanism of HIV reverse transcriptase inhibition by zinc," Journal of Biological Chemistry, vol. 286, no. 47, pp. 40433-40442, 2011.

[34] P. Gupta and F. Rapp, "Effect of zinc ions on synthesis of herpes simplex virus type 2-induced polypeptides," Experimental Biology and Medicine, vol. 152, no. 3, pp. 455-458, 1976.

[35] B. Fridlender, N. Chejanovsky, and Y. Becker, "Selective inhibition of herpes simplex virus type 1 DNA polymerase by zinc ions," Virology, vol. 84, no. 2, pp. 551-554, 1978.

[36] G. Kümel, S. Schrader, H. Zentgraf, H. Daus, and M. Brendel, "The mechanism of the antiherpetic activity of zinc sulphate," Journal of General Virology, vol. 71, no. 12, pp. 2989-2997, 1990.

[37] E. Ferrari, J. Wright-Minogue, J. W. S. Fang, B. M. Baroudy, J. Y. N. Lau, and Z. Hong, "Characterization of soluble hepatitis C virus RNA-dependent RNA polymerase expressed in Escherichia coli," Journal of Virology, vol. 73, no. 2, pp. 1649-1654, 1999.

[38] A. J. W. te Velthuis, S. H. E. van den Worm, A. C. Sims, R. S. Baric, E. J. Snijder, and M. J. van Hemert, "Zn2+ inhibits coronavirus and arterivirus RNA polymerase activity in vitro and zinc ionophores block the replication of these viruses in cell culture," PLoS Pathogens, vol. 6, no. 11, Article ID e1001176, 2010.

[39] H. R. Godfrey, N. J. Godfrey, J. C. Godfrey, and D. Riley, “A randomized clinical trial on the treatment of oral herpes with topical zinc oxide/glycine," Alternative Therapies in Health \& Medicine, vol. 7, no. 3, p. 49, 2001.

[40] R. B. Turner and W. E. Cetnarowski, "Effect of treatment with zinc gluconate or zinc acetate on experimental and natural colds," Clinical Infectious Diseases, vol. 31, no. 5, pp. 1202-1208, 2000. 
[41] Y. Murakami, T. Koyabu, A. Kawashima et al., "Zinc supplementation prevents the increase of transaminase in chronic hepatitis $\mathrm{C}$ patients during combination therapy with pegylated interferon .ALPHA.-2b and ribavirin," Journal of $\mathrm{Nu}$ tritional Science \& Vitaminology, vol. 53, no. 3, pp. 213-218, 2007.

[42] G. A. Eby, D. R. Davis, and W. W. Halcomb, "Reduction in duration of common colds by zinc gluconate lozenges in a double-blind study," Antimicrobial Agents and Chemotherapy, vol. 25, no. 1, pp. 20-24, 1984.

[43] L. E. Cuevas and A. Koyanagi, "Zinc and infection: a review," Annals of Tropical Paediatrics, vol. 25, no. 3, pp. 149-160, 2005.

[44] I. Wessels, B. Rolles, and L. Rink, "The potential impact of zinc supplementation on COVID-19 pathogenesis," Frontiers in Immunology, vol. 11, p. 1712, 2020.

[45] S. Sazawal, R. E. Black, S. Jalla, S. Mazumdar, A. Sinha, and M. K. Bhan, "Zinc supplementation reduces the incidence of acute lower respiratory infections in infants and preschool children: a double-blind, controlled trial," Pediatrics, vol. 102, no. 1, pp. 1-5, 1998.

[46] I. Abdulhamid, F. W. J. Beck, S. Millard, X. Chen, and A. Prasad, "Effect of zinc supplementation on respiratory tract infections in children with cystic fibrosis," Pediatric Pulmonology, vol. 43, no. 3, pp. 281-287, 2008.

[47] S. Rerksuppaphol and L. Rerksuppaphol, "A randomized controlled trial of zinc supplementation in the treatment of acute respiratory tract infection in Thai children," Pediatric Reports, vol. 11, no. 2, pp. 15-20, 2019.

[48] E. Finzi, "Treatment of SARS-CoV-2 with high dose oral zinc salts: a report on four patients," International Journal of Infectious Diseases, vol. 99, pp. 307-309, 2020.

[49] O. Patel, V. Chinni, J. El-Khoury et al., "A pilot double-blind safety and feasibility randomized controlled trial of high-dose intravenous zinc in hospitalized COVID-19 patients," Journal of Medical Virology, vol. 93, no. 5, pp. 3261-3267, 2021.

[50] J. A. Frontera, J. O. Rahimian, S. Yaghi et al., "Treatment with zinc is associated with reduced in-hospital mortality among COVID-19 patients: a multi-center cohort study," Research Square, 2020.

[51] K. Khanna, S. K. Kohli, R. Kaur et al., "Herbal immuneboosters: substantial warriors of pandemic covid-19 battle," Phytomedicine, vol. 85, Article ID 153361, 2020.

[52] M. Mukhtar, M. Arshad, M. Ahmad, R. J. Pomerantz, B. Wigdahl, and Z. Parveen, "Antiviral potentials of medicinal plants,” Virus Research, vol. 131, no. 2, pp. 111-120, 2008.

[53] S. Nolkemper, J. Reichling, F. Stintzing, R. Carle, and P. Schnitzler, "Antiviral effect of aqueous extracts from species of the Lamiaceae family against herpes simplex virus type 1 and type 2 in vitro," Planta Medica, vol. 72, no. 15, pp. 1378-1382, 2006.

[54] A. Munin and F. Edwards-Lévy, "Encapsulation of natural polyphenolic compounds; a review," Pharmaceutics, vol. 3, no. 4, pp. 793-829, 2011.

[55] J.-M. Song, K.-H. Lee, and B.-L. Seong, "Antiviral effect of catechins in green tea on influenza virus," Antiviral Research, vol. 68, no. 2, pp. 66-74, 2005.

[56] L. Bayan, P. H. Koulivand, and A. Gorji, "Garlic: a review of potential therapeutic effects," Avicenna Journal of Phytomedicine, vol. 4, no. 1, p. 1, 2014.

[57] M. Haidari, M. Ali, S. Ward Casscells 3rd, and M. Madjid, "Pomegranate (Punica granatum) purified polyphenol extract inhibits influenza virus and has a synergistic effect with oseltamivir," Phytomedicine, vol. 16, no. 12, pp. 1127-1136, 2009.

[58] H. Luo, Q.-l. Tang, Y.-x. Shang et al., "Can Chinese medicine Be used for prevention of corona virus disease 2019 (COVID19)? A review of historical classics, research evidence and current prevention programs," Chinese Journal of Integrative Medicine, vol. 26, no. 4, pp. 243-250, 2020.

[59] M. Ulasli, S. A. Gurses, R. Bayraktar et al., "The effects of Nigella sativa (Ns), Anthemis hyalina (Ah) and Citrus sinensis (Cs) extracts on the replication of coronavirus and the expression of TRP genes family," Molecular Biology Reports, vol. 41, no. 3, pp. 1703-1711, 2014.

[60] C.-W. Lin, F.-J. Tsai, C.-H. Tsai et al., "Anti-SARS coronavirus $3 \mathrm{C}$-like protease effects of Isatis indigotica root and plantderived phenolic compounds," Antiviral Research, vol. 68, no. 1, pp. 36-42, 2005.

[61] M. A. Alvarez, "Plant secondary metabolism chapter 3," in Plant Biotechnology for Health, pp. 15-31, Springer, Berlin, Germany, 2014.

[62] A. Scalbert, C. Manach, C. Morand, C. Rémésy, and L. Jiménez, "Dietary polyphenols and the prevention of diseases," Critical Reviews in Food Science and Nutrition, vol. 45, no. 4, pp. 287-306, 2005.

[63] F. Vizzari, M. Massányi, N. Knížatová et al., "Effects of dietary plant polyphenols and seaweed extract mixture on malerabbit semen: quality traits and antioxidant markers," Saudi Journal of Biological Sciences, vol. 28, no. 1, pp. 1017-1025, 2021.

[64] J. Long, P. Guan, X. Hu et al., "Natural polyphenols as targeted modulators in colon cancer: molecular mechanisms and Applications," Frontiers in Immunology, vol. 12, 2021.

[65] N. N. Besednova, B. G. Andryukov, T. S. Zaporozhets et al., "Antiviral effects of polyphenols from Marine Algae," Biomedicines, vol. 9, no. 2, p. 200, 2021.

[66] D. Milenkovic, T. Ruskovska, A. Rodriguez-Mateos, and C. Heiss, "Polyphenols could prevent SARS-CoV-2 infection by modulating the expression of miRNAs in the host cells," vol. 12, no. 5, pp. 1169-1182, 2021, Aging and Disease.

[67] L.-C. Chiang, L.-T. Ng, P.-W. Cheng, W. Chiang, and C.-C. Lin, "Antiviral activities of extracts and selected pure constituents of Ocimum basilicum," Clinical and Experimental Pharmacology and Physiology, vol. 32, no. 10, pp. 811-816, 2005.

[68] H.-B. Shin, M.-S. Choi, B. Ryu et al., "Antiviral activity of carnosic acid against respiratory syncytial virus," Virology Journal, vol. 10, no. 1, p. 303, 2013.

[69] M. Akram, I. M. Tahir, S. M. A. Shah et al., "Antiviral potential of medicinal plants against HIV, HSV, influenza, hepatitis, and coxsackievirus: a systematic review," Phytotherapy Research, vol. 32, no. 5, pp. 811-822, 2018.

[70] X. Cai, C. Li, G. Du, and Z. Cao, "Protective effects of baicalin on ligature-induced periodontitis in rats," Journal of Periodontal Research, vol. 43, no. 1, pp. 14-21, 2008.

[71] K. Kitamura, M. Honda, H. Yoshizaki et al., "Baicalin, an inhibitor of HIV-1 production in vitro," Antiviral Research, vol. 37, no. 2, pp. 131-140, 1998.

[72] H. Su, S. Yao, W. Zhao et al., "Discovery of baicalin and baicalein as novel, natural product inhibitors of SARS-CoV-2 3CL protease in vitro," BioRxiv, 2020.

[73] M. R. Loizzo, A. M. Saab, R. Tundis et al., "Phytochemical analysis andin vitro antiviral activities of the essential oils of seven Lebanon species," Chemistry and Biodiversity, vol. 5, no. 3, pp. 461-470, 2008. 
[74] J. Sharifi-Rad, B. Salehi, P. Schnitzler et al., "Susceptibility of herpes simplex virus type 1 to monoterpenes thymol, carvacrol, p-cymene and essential oils of Sinapis arvensis L., Lallemantia royleana Benth. and Pulicaria vulgaris Gaertn," Cellular and Molecular Biology, vol. 63, no. 8, pp. 42-47, 2017.

[75] C.-C. Wen, Y.-H. Kuo, J.-T. Jan et al., "Specific plant terpenoids and lignoids possess potent antiviral activities against severe acute respiratory syndrome coronavirus," Journal of Medicinal Chemistry, vol. 50, no. 17, pp. 4087-4095, 2007.

[76] H. Chen, Z. Lao, J. Xu et al., "Antiviral activity of lycorine against Zika virus in vivo and in vitro," Virology, vol. 546, pp. 88-97, 2020.

[77] Y.-N. Zhang, Q.-Y. Zhang, X.-D. Li et al., "Gemcitabine, lycorine and oxysophoridine inhibit novel coronavirus (SARS-CoV-2) in cell culture," Emerging Microbes \& Infections, vol. 9, no. 1, pp. 1170-1173, 2020.

[78] S. Li, C. Chen, H. Zhang et al., "Identification of natural compounds with antiviral activities against SARS-associated coronavirus," Antiviral Research, vol. 67, no. 1, pp. 18-23, 2005.

[79] C. Bailly, G. Vergoten, and Glycyrrhizin, "Glycyrrhizin: an alternative drug for the treatment of COVID-19 infection and the associated respiratory syndrome?" Pharmacology \& Therapeutics, vol. 214, Article ID 107618, 2020.

[80] P. Luo, D. Liu, and J. Li, "Pharmacological perspective: glycyrrhizin may be an efficacious therapeutic agent for COVID19," International Journal of Antimicrobial Agents, vol. 55, no. 6, Article ID 105995, 2020.

[81] B. Imelouane, M. Tahri, M. Elbastrioui, F. Aouinti, and A. Elbachiri, "Mineral contents of some medicinal and aromatic plants growing in eastern Morocco," Journal of $\mathrm{Ma}$ terials and Environmental Science, vol. 2, no. 2, pp. 104-111, 2011.

[82] F. Aouinti, H. Zidane, M. Tahri, J. P. Wathelet, and A. El Bachiri, "Chemical composition, mineral contents and antioxidant activity of fruits of Pistacia lentiscus L. from Eastern Morocco," Journal of Materials and Environmental Science, vol. 5, no. 1, pp. 199-206, 2014.

[83] N. El Hamdani and R. Fdil, "Evaluation of fatty acids profile and mineral content of Retama monosperma (L.) Boiss. of Morocco," Journal of Materials and Environmental Science, vol. 6, no. 2, pp. 538-545, 2015.

[84] A. M. Ebrahim, A. O. Alnajjar, M. E. Mohammed, A. M. Idris, M. E. A. Mohammed, and B. Michalke, "Investigation of total zinc contents and zinc-protein profile in medicinal plants traditionally used for diabetes treatment," Biometals, vol. 33, no. 1, pp. 65-74, 2020.

[85] E. El Maaiden, Y. El Kharrassi, M. Lamaoui, and L. Allai, "Variation in minerals, polyphenolics and antioxidant activity of pulp, seed and almond of different Ziziphus species grown in Morocco," Brazilian Journal of Food Technology, vol. 23, 2020.

[86] M. G. Sheded, I. D. Pulford, and A. I. Hamed, "Presence of major and trace elements in seven medicinal plants growing in the South-Eastern Desert, Egypt," Journal of Arid Environments, vol. 66, no. 2, pp. 210-217, 2006.

[87] S. Pradhan, S. Manivannan, and J. Tamang, "Proximate, mineral composition and antioxidant properties of some wild leafy vegetables," 2015, http://nopr.niscair.res.in/handle/ $123456789 / 30726$.

[88] S. Datta, B. K. Sinha, S. Bhattacharjee, and T. Seal, "Nutritional composition, mineral content, antioxidant activity and quantitative estimation of water soluble vitamins and phenolics by RP-HPLC in some lesser used wild edible plants," Heliyon, vol. 5, no. 3, Article ID e01431, 2019.

[89] M. Wati and M. Khabiruddin, "Variations in nutritional composition among different selected medicinal plants," Chemical Science Review and Letters, vol. 6, no. 21, pp. 88-93, 2018.

[90] S. Jabeen, M. T. Shah, S. Khan, and M. Q. Hayat, "Determination of major and trace elements in ten important folk therapeutic plants of Haripur basin, Pakistan," Journal of Medicinal Plants Research, vol. 4, no. 7, pp. 559-566, 2010.

[91] F. Karahan, I. I. Ozyigit, I. A. Saracoglu, I. E. Yalcin, A. H. Ozyigit, and A. Ilcim, "Heavy metal levels and mineral nutrient status in different parts of various medicinal plants collected from eastern Mediterranean region of Turkey," Biological Trace Element Research, vol. 197, no. 1, pp. 316-329, 2020.

[92] V. Okatan, A. M. Çolak, S. F. Güçlü, and M. Gündoğdu, "the comparison of antioxidant compounds and mineral content in some pomegranate (Punica granatum L.) genotypes grown in the east of Turkey," Acta Sci Pol Hortorum Cultus, vol. 17, no. 4, p. 17, 2018.

[93] N. K. Achi, C. Onyeabo, C. A. Ekeleme-Egedigwe, and J. C. Onyeanula, "Phytochemical, proximate analysis, vitamin and mineral composition of aqueous extract of Ficus capensis leaves in South Eastern Nigeria," Journal of Applied Pharmaceutical Science, vol. 7, no. 3, pp. 117-122, 2017.

[94] C. Paca, L. Mărghitaş, D. Dezmirean et al., "Medicinal plants based products tested on pathogens isolated from mastitis milk," Molecules, vol. 22, no. 9, p. 1473, 2017.

[95] G. Matev, P. Dimitrova, N. Petkova, I. Ivanov, and D. Mihaylova, "Antioxidant activity and mineral content of rocket (eruca sativa) plant from Italian and Bulgarian origins," Journal of Microbiology, Biotechnology and Food Sciences, vol. 8, no. 2, pp. 756-759, 2018. 